RESEARCH ARTICLE

\title{
Antimicrobial Metabolites from Ectomycorrhizal Fungus, Pisolithus tinctorius (Pers.) Coker against Soil Borne Plant Pathogens
}

\author{
Ganeshkumar $\mathrm{P}^{1}$, Krishnamoorthy A. $\mathbf{S}^{1 *}$, Sangeetha $\mathrm{C}^{1}$, Nakkeeran $\mathbf{S}^{1}$, Sivakumar $\mathbf{U}^{2}$ and \\ Thiribhuvanamala $\mathbf{G}^{1}$ \\ ${ }^{1}$ Department of Plant Pathology, Tamil Nadu Agricultural University, Coimbatore -641002 , Tamil Nadu, India \\ ${ }^{2}$ Biocatalysts Laboratory, Dept. of Agricultural Microbiology, Tamil Nadu Agricultural University, Coimbatore - 641 003, Tamil Nadu, India
}

\begin{abstract}
Pisolithus tinctorius (Pers.) Coker is an ectomycorrhizal fungus that forms an abundant wealth of biomass in the forest ecosystem, with an untapped treasure of bioactive compounds and secondary metabolites having multifaceted use in health and agrochemical industries. The hidden potential of this fungus is tapped in the current study by using MTP1 isolate of $P$. tinctorius. The secondary metabolites of $P$. tinctorius were extracted and tested for their inhibitory efficacy against major soil-borne plant pathogens viz., Fusarium oxysporum f. sp. Iycopersici (Sacc.) Synder and Hansen; Macrophomina phaseolina (Goid); Rhizoctonia solani (Kuhn) and Sclerotium rolfsii (Sacc). The cell-free culture (CFC) filtrate of P.tinctorius showed the maximum mycelial inhibition of F. o. f. sp. lycopersici (52.00\%); R. solani (51.92\%) and M. phaseolina (48.23\%). However, the CFC filtrate mixture did not inhibit the growth of S. rolfsii. The GC-MS analysis of biomolecules composite of ethyl acetate fraction of CFC filtrate indicated the presence of compounds belonging to the nature of fatty acids, aromatic alcohol, and flavonoids. The reduction in the growth of the test pathogens with the increase in the concentration of CFC filtrate and the presence of several unknown compounds in P. tinctorius warrants further study with the purified form of antifungal biomolecules in reducing root rots and wilts incited by the soil-borne phytopathogens.
\end{abstract}

Keywords: Pisolithus tinctorius; Metabolites; Pathogens inhibition.

\section{INTRODUCTION}

Ectomycorrhizal fungi (ECM) are major components of the soil fungal communities in most of the forests around the world and they are ecologically and economically important (Mello et al., 2006). ECM fungi are obligate in plants of Betulaceae, Pinaceae, and Fagaceae families. Forest tree species like pines and eucalyptus depend on ECM symbiosis, without which they will not grow (Smith and Read, 1997) and belong to multiple families from the phylum like Basidiomycota, Ascomycota, and Zygomycota (Bruns et al., 2002). Globally, as many as 10,000 fungal species and approximately 8,000 plant species seem to be involved in the ECM relationship (Taylor and Alexander, 2005). Inoculation of forest nurseries with selected ectomycorrhizae is very much important in improving and establishing large-scale plantations (Marx et al., 1994). Although lots of information has been generated in temperate regions, knowledge of the ectomycorrhizal relationship with tropical tree species seems limited.

These ECM fungi are known to offer disease resistance to their hosts by providing a physical barrier to the root cells called the mantle and Hartig net (Hibbett and Matheny, 2009) and thereby prevent the penetration of phytopathogenic fungi. They also divert surplus carbohydrates available on root surfaces, thereby reducing the chemotaxis (Zeng et al., 2003). Besides, ECM fungi also support the growth of other beneficial microflora in the rhizosphere region by extracellular secretion of several biomolecules having potential benefits (Zak, 1964; Bowers et al., 1986). Production of antimicrobial compounds by ECM fungi against phytopathogens has been reported in over 100 species (Marx, 1973). Pisolithus tinctorius (Pers.) Coker and Couch (syn. $=P$. arhizus (Scop. Pers.) Rauschert) is an ECM fungus that belongs to the family: Sclerodermataceae; order: Sclerodermatales and phylum: Basidiomycota. The juvenile fruiting bodies are known to be edible and at maturity, they

$107|10-12| 1$ 
are used for the production of bright brown and black dyes (Lincoff, 1984). This fungus has acquired economic importance due to its basidiospore inoculum forming a specific ectomycorrhizal relationship with several tree species; it helps the host plants substantially in the uptake of mineral nutrients, thereby literally creating large scale forest cover (Baumert et al., 1997; Lazarevic et al., 2012).

Besides its relevance as an ECM fungus, $P$. tinctorius forms an abundant wealth of biomass, which has not yet been appropriately explored in India. Most promisingly, the secondary metabolite fractions of the fruiting bodies of $P$. tinctorius viz., lanostanetriterpene and naphthalenoidpulvinic acid derivatives are known to possess antiviral and immunomodulatory properties (Fujimoto et al., 1994). Ross and Marx in 1973 indicated that $P$. tinctorius had the potential to protect seedlings from a variety of soil-borne pathogens, including Phytophthora, Fusarium, Rhizoctonia, and Cylindrocarpon spp. Evidence from Marx (1970) attributed solely that the protective effect of $P$. tinctorius isolates was due to the provision of a physical barrier by the fungal sheath to the invading pathogenic fungi, with no evidence of the production of antimicrobial compounds. However, the function of protecting the host plants against microbial invaders was demonstrated mainly due to the production of antibiotic compounds viz., pisolithin $\mathrm{A}$, and $\mathrm{B}$, from the cultures of $P$. tinctorius, by Tsantrizos et al. (1991). Both the compounds exhibited strong antifungal activities causing hyphal lysis and inhibition of spore germination in the case of several phytopathogenic and dermatogenic fungi.

Soil-borne plant pathogens are very important worldwide because of their severe infection, leading to huge yield loss in several crop plants (Oerke, 2006). Most of the soil-borne plant pathogens produce symptoms like root rot, damping-off, tissue discoloration and wilting. These organisms persist in soil for a prolonged period and produce resilient survival structures such as chlamydospores and sclerotia (Hao et al., 2003). The most important genera of soil-borne plant pathogens include Fusarium, Macrophomina, Pythium, Phytophthora, Rhizoctonia, Sclerotium, Sclerotinia and Verticillium. In light of this supporting information, the present investigation has been framed to test the antimicrobial potential of bioactive compounds of $P$. tinctorius against the soil-borne plant pathogenic fungi viz., Fusarium oxysporum f. sp. lycopersici, Macrophomina phaseolina, Rhizoctonia solani and Sclerotium rolfsii. The present study aimed to evaluate the effect of metabolites produced by P. tinctorius on various phytopathogens.

\section{MATERIAL AND METHODS}

All experiments were conducted in the Mushroom Research Laboratory, Department of Plant Pathology, Tamil Nadu Agricultural University (TNAU), Coimbatore. Pure cultures of F. o. f. sp. lycopersici, M. phaseolina, R. solani and S. rolfsii were obtained from the culture collection facility in the Department of Plant Pathology, TNAU, Coimbatore.

\section{Isolation and Pure Culturing of P. tinctorius}

For tissue isolation, the fruiting bodies of $P$. tinctorius collected from the forest of Mettupalayam, Coimbatore district (named as MTP 1) were cut into pieces of 10-12 $\mathrm{mm}^{3}$, placed in running tap water for $10 \mathrm{~min}$ and then in $70 \%$ ethanol for $1 \mathrm{~min}$. The pieces were rinsed with sterile distilled water and placed in 20 per cent $(\mathrm{w} / \mathrm{v})$ commercial bleach $(5 \%$ active chlorine) for $10 \mathrm{~min}$. Once again, the pieces were rinsed four times with sterile distilled water. Later, the larger pieces were cut into smaller ones $\left(5 \mathrm{~mm}^{3}\right)$ for tissue isolation. Isolation of the fungus and pure culturing was done using Modified Melin Norkrans medium (MMN medium). The $\mathrm{pH}$ of the growth medium was adjusted to 4.5 - 5.0. Sterilized pieces of sporocarps were placed at the center of Petri dishes containing sterile MMN medium and incubated in darkness at $30{ }^{\circ} \mathrm{C}$ for $30 \mathrm{~d}$. After the completion of growth in Petri plates, single hyphal tip method was followed Rangaswami, 1972 for maintenance of pure culture and stored at $4{ }^{\circ} \mathrm{C}$ for further studies.

\section{Extractions of bioactive compounds from the culture filtrate of $P$. tinctorius}

Four mycelial discs measuring $6 \mathrm{~mm}$ diameter each, cut from the margin of a $14 \mathrm{~d}$ old colony of $P$. tinctorius MTP1, was inoculated to $100 \mathrm{~mL}$ of sterilized MMN broth (adjusted to pH 5.5 with sodium citrate - citric acid buffer) taken in 250 $\mathrm{mL}$ conical flasks. The flasks were later placed on a rotary shaker at $100 \mathrm{rpm}$; incubated at $30{ }^{\circ} \mathrm{C}$ in darkness for $30 \mathrm{~d}$. After incubation, the culture medium and the mycelial mat were separated by filtration through Whatman No.1 filter paper. The filtrate was further centrifuged at 10,000 $\mathrm{g}$ and the mycelium-free culture filtrate was extracted with organic solvents viz., methanol, chloroform, ethyl acetate, and water ( $\mathrm{v} / \mathrm{v}$ ) sequentially. Liquid-liquid extraction was carried out three to four times for each solvent. The organic extracts were evaporated under reduced pressures using a rotary evaporator to obtain residues. The condensate was dissolved in dimethyl sulfoxide (DMSO) and filtered with a membrane filter $(0.2 \mu \mathrm{m})$ and stored at $4{ }^{\circ} \mathrm{C}$ for further study. 


\section{Bioassay of secondary metabolites from CFC filtrate of $P$. tinctorius}

The culture filtrates collected at different growth intervals viz., 15, 30, and 45 d were aseptically mixed separately, with $100 \mathrm{~mL}$ of sterilized molten PDA medium @ 1000 ppm and allowed to solidify. At the center of the poisoned medium, a $5 \mathrm{~mm}$ mycelial disc of test pathogen was introduced and the Petri plates were incubated at $28{ }^{\circ} \mathrm{C}$. Constant observations were made and the per cent inhibition of mycelial growth of pathogenic fungi viz., F. oxysporum f. sp. lycopersici, M. phaseolina, $R$. solani and S. rolfsii were recorded up to $7 \mathrm{~d}$. Five replications along with control plates were maintained for each treatment.

\section{Assessment of mycelial inhibition}

In all the experiments conducted to test the mycelial inhibition, the following formula was used to record the per cent inhibition of mycelial growth over control.

Per cent inhibition over control = Mycelial growth in control - Mycelial growth in treatment / Mycelial growth in control x 100 .

\section{Gas Chromatography-Mass spectrometry (GC-MS)}

Characterization of biomolecules extracted from culture filtrate was done by GC-MS analysis. Volatile components were identified by GC-MS using a column Elite-5MS (100\% Dimethylpolysiloxane), $30 \times 0.25 \mathrm{~mm} \times 0.25 \mu \mathrm{m}$ df equipped with GC Clarus 500 Perkin Elmer. The turbo mass-gold-perkin- Elmer detector was used. The carrier gas flow rate was

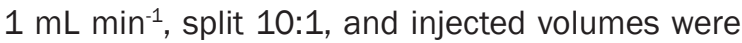
$3 \mu \mathrm{L}$. The column temperature was maintained initially at $130{ }^{\circ} \mathrm{C}$ at the rate of $10^{\circ} \mathrm{C} \mathrm{min}-1$. No hold followed by an increase up to $270^{\circ} \mathrm{C}$ at the rate of $5^{\circ} \mathrm{C} / \mathrm{min}^{-9} \mathrm{~min}$ (hold). The injector temperature was $250^{\circ} \mathrm{C}$ and this temperature was held constant for $36 \mathrm{~min}$. The electron impact energy was $70 \mathrm{eV}$, Juliet line temperature was set at $2000^{\circ} \mathrm{C}$ and the source temperature was set at $200^{\circ} \mathrm{C}$. Electron impact (EI) mass scan $(\mathrm{m} / \mathrm{z})$ was recorded in the 45-450 aMU range. Using computer searches on the NIST Version 2011 MS data library and comparing the spectrum obtained through GC/MS, the compounds present in the crude sample were identified.

\section{Statistical Analyses}

Statistical analyses and design of experiments in all the studies conducted were made following the methods suggested by Gomez and Gomez (1984). Following the analysis of variance (ANOVA), the mean differences were adjusted with Duncan's Multiple Range Test (DMRT) using the statistical computer package program, IRRISTAT version- 92.

\section{RESULTS AND DISCUSSION}

Soil-borne plant pathogens are the causal agents of root rots, damping-off, and vascular wilts in almost all the plants resulting in heavy crop losses. These pathogenic fungi also persist for long periods in the soil in the absence of susceptible hosts. Although several fungicides are in use, increased awareness towards environmental protection, and forceful development of resistance in pathogens, scientists have always been looking for alternate strategies and organic products to manage soil-borne plant pathogens. Macrobasidiomycetous fungi are known to produce a large number of biologically active compounds with antibacterial, antifungal, antiviral,

Table 1. Effect of secondary metabolites of $P$. tinctorius isolate (45 d old CFC filtrate) on pathogenic fungi

\begin{tabular}{|c|c|c|c|c|c|c|c|c|}
\hline \multirow{2}{*}{$\begin{array}{c}\text { Secondary } \\
\text { Metabolites } \\
\text { mixture (ppm) }\end{array}$} & \multicolumn{2}{|c|}{$\begin{array}{c}\text { F. oxysporum f.sp. } \\
\text { lycopersici }\end{array}$} & \multicolumn{2}{|c|}{ M. phaseolina } & \multicolumn{2}{|c|}{ R. solani } & \multicolumn{2}{|c|}{ S. rolfsii } \\
\hline & $\begin{array}{l}\text { Growth } \\
\text { (mm) }\end{array}$ & $\begin{array}{l}\text { Per cent } \\
\text { inhibition }\end{array}$ & $\begin{array}{l}\text { Growth } \\
\text { (mm) }\end{array}$ & $\begin{array}{l}\text { Per cent } \\
\text { inhibition }\end{array}$ & $\begin{array}{l}\text { Growth } \\
\text { (mm) }\end{array}$ & $\begin{array}{l}\text { Per cent } \\
\text { inhibition }\end{array}$ & $\begin{array}{l}\text { Growth } \\
\text { (mm) }\end{array}$ & $\begin{array}{l}\text { Per cent } \\
\text { inhibition }\end{array}$ \\
\hline 500 & $\begin{array}{l}83.00^{c} \\
(65.68)\end{array}$ & 7.78 & $\begin{array}{l}90.00^{c} \\
(71.57)\end{array}$ & 0.00 & $\begin{array}{l}74.50^{c} \\
(59.63)\end{array}$ & 17.22 & $\begin{array}{r}90.00 \\
(71.57)\end{array}$ & 0.00 \\
\hline 1000 & $\begin{array}{r}64.33^{b} \\
(53.33)\end{array}$ & 28.52 & $\begin{array}{l}73.00^{b} \\
(58.70)\end{array}$ & 18.89 & $\begin{array}{l}65.00^{b} \\
(53.73)\end{array}$ & 27.70 & $\begin{array}{r}90.00 \\
(71.57)\end{array}$ & 0.00 \\
\hline 1500 & $\begin{array}{l}43.20^{a} \\
(41.10)\end{array}$ & 52.00 & $\begin{array}{l}48.23^{a} \\
(43.98)\end{array}$ & 46.41 & $\begin{array}{l}43.27^{a} \\
(41.13)\end{array}$ & 51.92 & $\begin{array}{r}90.00 \\
(71.57)\end{array}$ & 0.00 \\
\hline Control & $\begin{array}{l}90.00^{d} \\
(71.57)\end{array}$ & 0.00 & $\begin{array}{l}90.00^{\circ} \\
(71.57)\end{array}$ & 0.00 & $\begin{array}{l}90.00^{d} \\
(71.57)\end{array}$ & 0.00 & $\begin{array}{r}90.00 \\
(71.57)\end{array}$ & 0.00 \\
\hline CD (0.05) & 2.172 & & 1.595 & - & 1.908 & - & & - \\
\hline
\end{tabular}

Values in parentheses are arcsine transformed, Means followed by a common letter is not significantly different by DMRT ( $p=0.05$ per cent) 
cytotoxic, or hallucinogenic activities (Benedict and Brady, 1972). These compounds from wild macrofungi exhibited strong inhibition of the growth of an array of saprophytic and phytopathogenic fungi. Edible macrofungi such as Hericium erinaceum, Lentinus edodes, Flammulina velutipes and Ganoderma lucidum were reported to be antagonistic to human pathogens (Breene, 1990). But, for the strobilurin group of biomolecules, most of these investigations have focused on the therapeutics of human pathogens, although great scope exists to contain plant pathogens. The current research was, therefore, initiated to test the performance of bioactive compounds or secondary metabolites of an ectomycorrhizal fungus, Pisolithus tinctorius, against soil-borne plant pathogens viz., F. oxysporum f. sp. lycopersici, M. phaseolina, R. solani and S. rolfsii. The results obtained were discussed hereunder.

Table 2. Per cent recovery of bioactive compounds from cell free culture filtrate of P. tinctorius

\begin{tabular}{rrr}
\hline \multirow{2}{*}{ Solvent used @100mL } & \multicolumn{2}{c}{ CFC filtrate condensate } \\
\cline { 2 - 3 } & (mg) & Per cent \\
\hline Ethyl acetate & 5.70 & 0.0057 \\
Methanol & 3.50 & 0.0035 \\
Chloroform & 2.30 & 0.0023 \\
Water & 1.70 & 0.0017 \\
\hline
\end{tabular}

*Each sample of biomolecules mixture was weighed after condensing the solvents in a vacuum flask evaporator at $45^{\circ} \mathrm{C}$ for $30 \mathrm{~min}$.

\section{Effect of Cell-Free Culture (CFC) filtrate of $P$. tinctorius isolates MTP1 on plant pathogens}

The results revealed the presence of antifungal metabolites in $45 \mathrm{~d}$ old CFC at $1500 \mathrm{ppm}$ concentration inhibited F. oxysporum f. sp. lycopersici, $M$. phaseolina and $R$. solani with per cent inhibitions of $52.00,46.15$ and $51.92 \%$, respectively (Table 1 ). But, there was no inhibition in the case of S. rolfsii indicating that the secondary metabolite mixture produced by $P$. tinctorius isolate MTP1 is not capable of inhibiting S. rolfsii. When compared to 15 and $30^{\text {th }} \mathrm{d}$ old culture filtrate, the $45 \mathrm{~d}$ old culture filtrate showed a yellowish-brown colored pigment diffusing constantly from the interface of the mycelial mat and the liquid medium supporting its growth. Probably, $45 d$ is the time taken by the fungus to reach the stationary phase of its growth. It is obvious to note that the results of our preliminary experiments and earlier reports prove the slow-growing nature of $P$. tinctorius, taking almost $30 \mathrm{~d}$ and above to complete the lag and log phase. Kope and Fortin (1990) reported that the optimum incubation period for the production of the metabolites by $P$. tinctorius liquid culture was 42-56 d. Further observations of the color change and estimation of components in the metabolite mixture beyond $45 d$ might reveal the facts. Optimization of the stationary phase to get the maximum levels of secondary metabolite mixture is suggested for future studies. In a similar attempt, extracellular metabolites of the ectomycorrhizal fungi Amanita citrina, Laccaria bicolor, L. laccata, P. tinctorius, Suillus brevis, Tricholoma flavovirens and T. pessundatum had inhibited the growth of the tested fungi up to $83.0 \%$ (Kope and Fortin, 1990). They also reported that the CFC filtrate of $P$. tinctorius causes hyphal lysis in two phytopathogens viz., Truncatella hartigii and R. paraticola (Kope and Fortin, 1989; Kope and Fortin, 1990).

\section{Extraction and recovery of biomolecules from $P$. tinctorius isolate MTP1}

In the present study, biomolecules were extracted from $45 \mathrm{~d}$ old CFC filtrate using different polar and non-polar solvents. After, a series of extraction processes, the per cent recovery of biomolecules in solvent and water fractions was calculated on a dry weight basis. Ethyl acetate fraction of the samples was always found to give the maximum recovery of biomolecules $(0.0057 \%$ from $\mathrm{CFC}$ filtrate condensate) (Table 2). In a similar study, Ameri et al. (2011) reported that the ethyl acetate fraction of the sporocarps of $P$. albus exhibited increased levels of recovery of biomolecules (up to $40 \mathrm{mg}$ per $100 \mathrm{~mL}$ of solvent which is equivalent to 0.4 per cent). The poor recovery of biomolecules in water fraction indicates that the composite biomolecules do not dissolve in aqueous solution. The ethyl acetate fraction of CFC filtrate was subjected to GC-MS analysis, just for profiling the compounds.

\section{Effects of ethyl acetate fraction of bioactive molecules of $P$. tinctorius isolate MTP1}

Bioactive compounds were found to be diversely distributed in the fruiting bodies, CFC filtrate and the mycelial mat of $P$. tinctorius. Among the different solvents used for extraction and recovery of bioactive compounds, ethyl acetate fractions of both fruiting body extract and CFC filtrate condensate had exhibited considerable antifungal activity against F. oxysporum f. sp. lycopersici, M. phaseolina and $R$. solani whereas, methanol, chloroform, and aqueous extracts were not effective in controlling any of the test pathogens. The results also indicated the ineffectiveness of even the ethyl acetate fraction against S. rolfsii. More interestingly, the ethyl acetate fraction of CFC filtrate condensate at a concentration of $150 \mu \mathrm{l}$ showed the maximum Inhibition of F. oxysporum f. sp. lycopersici colony $\left(920 \mathrm{~mm}^{2}\right)$. In the case of $R$. solani and $M$. phaseolina, CFC filtrate condensate fraction showed the maximum inhibition of $890 \mathrm{~mm}^{2}$ and $870 \mathrm{~mm}^{2}$, respectively (Table 3). The

$107 \mid 10-12$ | 4 
reason for this differential expression of antimicrobial activities might be due to the differences in the bioactive compositions, concentrations, methods of extraction, and mechanism of action of the available active ingredients. Imtiaj and Lee (2007) also reported that the ethanol extract of non-edible macrofungi, Stereum ostrea had contained antifungal properties against certain plant pathogenic fungi including Colletotrichum gloeosporioides, C. miyabeanus, and Botrytis cinerea; and the extract was found to significantly reduce the mycelial growth of the pathogenic fungi.

In a similar study, Sangeetha et al. (2015) had also evaluated the methanolic fraction of mycelium borne biomolecules of Ophiocordyceps sinensis against F. oxysporum f.sp.lycopersici, F. oxysporum f.sp.cubense, M.phaseolina and R.solani. The result exhibited 48.67 per cent of inhibition against

Table 3. Effect of various fractions of bioactive molecules of $P$. tinctorius (CFC filtrate condensate) against different soil borne plant pathogens.

\begin{tabular}{|c|c|c|c|c|c|}
\hline \multirow{2}{*}{ Bioactive molecules } & \multirow{2}{*}{ Concentrations ( $\mu \mathrm{l})$} & \multicolumn{4}{|c|}{ Inhibition $\left(\mathrm{mm}^{2}\right)$} \\
\hline & & F. o.f. sp. lycopersici & M. phaseolina & R. solani & S. rolfsii \\
\hline \multirow{3}{*}{ Ethyl acetate fraction } & 50 & $440.00^{\circ}(20.52)$ & $410^{c}(17.64)$ & $430^{c}(18.20)$ & $\begin{array}{r}0.00 \\
(1.12)\end{array}$ \\
\hline & 100 & $720.00^{\mathrm{b}}(23.26)$ & $\begin{array}{r}640 \\
(21.70)\end{array}$ & $780^{\mathrm{b}}(24.92)$ & $\begin{array}{r}0.00 \\
(1.12)\end{array}$ \\
\hline & 150 & $920.00^{a}(29.10)$ & $870^{a}(28.13)$ & $890^{\mathrm{a}}(29.00)$ & $\begin{array}{r}0.00 \\
(1.12)\end{array}$ \\
\hline \multirow{5}{*}{ Methanol fraction } & 50 & $\begin{array}{r}0.00 \\
(1.12)\end{array}$ & $\begin{array}{r}0.00 \\
(1.12)\end{array}$ & $\begin{array}{r}0.00 \\
(1.12)\end{array}$ & $\begin{array}{r}0.00 \\
(1.12)\end{array}$ \\
\hline & \multirow{2}{*}{100} & 0.00 & 0.00 & 0.00 & 0.00 \\
\hline & & (1.12) & (1.12) & (1.12) & $(1.12)$ \\
\hline & \multirow{2}{*}{150} & 0.00 & 0.00 & 0.00 & 0.00 \\
\hline & & (1.12) & (1.12) & (1.12) & $(1.12)$ \\
\hline \multirow{6}{*}{ Chloroform fraction } & \multirow{2}{*}{50} & 0.00 & 0.00 & 0.00 & 0.00 \\
\hline & & (1.12) & (1.12) & (1.12) & $(1.12)$ \\
\hline & \multirow{2}{*}{100} & 0.00 & 0.00 & 0.00 & 0.00 \\
\hline & & (1.12) & (1.12) & (1.12) & $(1.12)$ \\
\hline & \multirow{2}{*}{150} & 0.00 & 0.00 & 0.00 & 0.00 \\
\hline & & (1.12) & (1.12) & (1.12) & $(1.12)$ \\
\hline \multirow{6}{*}{ Water residue } & \multirow{2}{*}{50} & 0.00 & 0.00 & 0.00 & 0.00 \\
\hline & & (1.12) & (1.12) & (1.12) & $(1.12)$ \\
\hline & \multirow{2}{*}{100} & 0.00 & 0.00 & 0.00 & 0.00 \\
\hline & & (1.12) & (1.12) & (1.12) & $(1.12)$ \\
\hline & \multirow{2}{*}{150} & 0.00 & 0.00 & 0.00 & 0.00 \\
\hline & & (1.12) & (1.12) & (1.12) & $(1.12)$ \\
\hline Control (+) & & 0.00 & 0.00 & 0.00 & 0.00 \\
\hline Sterile water & 150 & (1.12) & (1.12) & (1.12) & $(1.12)$ \\
\hline \multirow{2}{*}{ Control (DMSO) (-) } & \multirow{2}{*}{150} & 0.00 & 0.00 & 0.00 & 0.00 \\
\hline & & (1.12) & (1.12) & (1.12) & (1.12) \\
\hline$C D$ & & 184.2 & 174.0 & 178.5 & \\
\hline
\end{tabular}

Values in parentheses are arcsine transformed, Means followed by a common letter is not significantly different by DMRT ( $p=0.05$ per cent) 
F. oxysporum f. sp. lycopersici. Shrestha et al. (2005) reported the antibacterial activity of metabolites of Pisolithus spp against a spectrum of Gram-Negative and Gram-Positive bacteria. Ameri et al. (2011) also concluded that the ethyl acetate fractions of the sporocarps of $P$. albus showed the maximum inhibition for Staphylococcus aureus. Waser (2002) reported that many macrofungi contained bioactive compounds, with antifungal, antibacterial and antiviral activities. In a separate study, the methanol extract of Phellinus was reported to possess better antifungal potentials than aqueous extract (Balakumar et al., 2011). The methanol extract was found to significantly inhibit the mycelial growth of five fungal pathogens viz., Penicillium sp., Aspergillus fumigatus, A. niger, A. flavus and Mucor indicus.

Table 4. GC-MS analysis of the condensate of CFC filtrate (ethyl acetate fraction) of $P$. tinctorius

\begin{tabular}{|c|c|c|c|c|c|c|}
\hline $\mathbf{R T *}$ & Compound name & Structure & $\begin{array}{l}\text { Molecular } \\
\text { formula }\end{array}$ & $\mathbf{M W}$ * & $\begin{array}{c}\text { Peak area } \\
\text { per cent }\end{array}$ & $\begin{array}{r}\text { Nature of } \\
\text { compound }\end{array}$ \\
\hline 7.85 & Benzeneethanol & & $\mathrm{C}_{8} \mathrm{H}_{10} \mathrm{O}$ & 122 & 0.25 & $\begin{array}{l}\text { Aromatic } \\
\text { alcohol }\end{array}$ \\
\hline 13.82 & 2-Allyl-5-t- butylhydroquinone & & $\mathrm{C}_{13} \mathrm{H}_{18} \mathrm{O}_{2}$ & 206 & 0.43 & Not known \\
\hline 17.65 & $\begin{array}{l}\text { 1,2-Benzenedicarboxylic acid, } \\
\text { diethyl ester }\end{array}$ & & $\mathrm{C}_{12} \mathrm{H}_{14} \mathrm{O} 4$ & 222 & 1.39 & Fatty acid \\
\hline 26.64 & $\begin{array}{l}\text { 1,4-diaza-2,5-dioxo isobutyl } \\
\text { bicyclo[4.3.0]nonane }\end{array}$ & & $\mathrm{C}_{11} \mathrm{H}_{18} \mathrm{~N}_{2} \mathrm{O}_{2}$ & 210 & 1.85 & - \\
\hline 33.29 & $\begin{array}{l}\text { Benz[j]aceanthrylene, } \\
\text { 1,2,6,7,8,9,10,12b-octahydro- } \\
\text { 3-methyl-(Cholanthrene) }\end{array}$ & & $\mathrm{C}_{21} \mathrm{H}_{22}$ & 274 & 66.51 & - \\
\hline 38.95 & Phthalic acid, nonyl 4-octyl ester & & $\mathrm{C}_{25} \mathrm{H}_{40} \mathrm{O}_{4}$ & 404 & 0.64 & Fatty acid \\
\hline
\end{tabular}

${ }^{*}$ RT- Retention Time ; *MW-Molecular weight.

\section{Characterization of bioactive compounds through GC-MS}

The ethyl acetate fraction of CFC filtrate condensate was subjected to GC-MS analysis and the result revealed that, CFC filtrate condensate contained compounds viz., benzene-ethanol; 2-Allyl-5-t-butyl hydroquinone; 1,2-benzene dicarboxylic acid; diethyl ester; 1,4-diaza-2, 5-dioxo-isobutyl bicyclo [4.3.0] nonane; Benz[j]aceanthrylene,1,2,6,7,8,9,10,12boctahydro-3- methyl; benz[j]aceanthrylene, 1,2,6,7,8,9,10,12b-octahydro- 3-methyl(Cholanthrene); Phthalic acid nonyl 4-octyl ester (Table 4). Among these, benzene ethanol (0.25 per cent) is aromatic alcohol expressed at 7.85 RT
(Retention Time). Fraud et al. (2003) had observed anti-oxidant and antibacterial activity of this compound against certain Gram-Negative bacteria and mycobacteria.

Similarly, 2-Allyl-5-t-butyl hydroquinone (0.43 per cent) was found to be expressed at 13.82 RT and its biological activity was not known. Likewise, at 17.65 RT another compound named 1, 2-benzenedicarboxylicacid diethyl ester (1.39 percent) was identified (Fig 1). This is a fatty acid and its antioxidant, antifungal activities against Aspergillus niger, Candida albicans, and $A$. flavus; and antibacterial activity against Escherichia coli, Staphylococcus aureus,

$107 \mid 10-12$ | 6 
S. epidermidis, Nitrosapira has already been reported by Mushtaq et al. (2013). More interestingly, 1,4-diaza-2,5-dioxo-iso-butyl-bicyclo [4.3.0] nonane (1.85 per cent), a cyclic di-peptide was found at 26.64 RT. Holden et al. (2000) also identified a compound similar to this from Pseudomonas fluorescens culture filtrate, which was found to play an important role in quorum sensing, favoring molecular cross-talk among the microorganisms. Likewise, the compound Benz [j] aceanthrylene, $1,2,6,7,8,9,10,12$ b - octahydro - 3 - methyl (cholahthrene) (66.51 per cent), which was found to be expressed at 33.29 RT had earlier been reported by Salomi et al. (1991), who proved its anti-tumor activity. Similarly, 1,4-diaza-2,5-dioxo-isobutyl bicyclo [4.3.0] nonane (0.60 per cent) was found expressed at 26.64 RT.

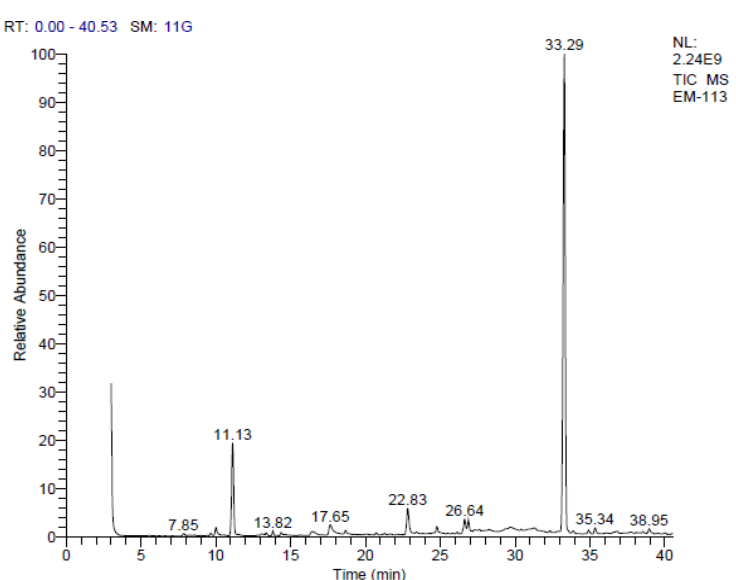

\section{Fig 1.Total ion chromatogram (TIC) of biomolecules identified from CFC of $P$. tinctorius through GC-MS}

This compound was known to possess antibacterial activity against three different pathogenic bacteria viz., Aeromonas hydrophila, Edwardsiella tarda and Vibrio ordalli (Gohar et al., 2010). The fatty acid fraction, namely, Phthalic acid nonyl 4-octyl ester (0.64 per cent) found expressed at 38.95 RT was found to possess insecticidal activity on Sitophilus zeamais, Tribolium castaneum and Rhyzopertha dominica (Lucie et al., 2013). Further studies to recover these useful compounds in large quantities from $P$. tinctorius will have multifaceted benefits. Interestingly, several unknown compounds were also found expressed during GC-MS analysis; and their potential role in inhibiting the test pathogens viz., F. oxysporum f. sp. lycopersici, M. phaseolina, R. solani and even S. rolfsii need to be elucidated. Conclusively, the results of the present investigations reveal evidence that the bioactive compounds of $P$. tinctorius isolate MTP1 could be potentially explored for the management of soil-borne plant pathogens that cause wilt, root rot and seedling blight diseases in crop plants.

\section{CONCLUSION}

The results of the present investigations revealed that the bioactive compounds of $P$. tinctorius MTP 1 could be potentially explored for the management of soil-borne plant pathogens that induce wilt, root rot and seedling blight diseases in crop plants. In addition, such compounds may also be useful in plant growth promotion, quorum sensing, nodulation and stress tolerance. Further studies will be required to recover these useful compounds in large quantities from $P$. tinctorius will have multifaceted benefits. Interestingly, several unknown compounds were also found expressed during GC-MS analysis; and their potential role in inhibiting the test pathogens viz., F. oxysporum f.sp. lycopersici, M. phaseolina, $R$. solani and S. rolfsii needs to be elucidated.

\section{REFERENCES}

Ameri, A., Ghadge, C., Vaidya, G.J. and S. S. Deokule. 2011. Anti-Staphylococcus aureus activity of Pisolithus albus from Pune, India. J. Med. Plants Res., 5: 527-532.

BalaKumar, R., Sivaprakasam, E., Kavitha, D., Sridhar, S. and J. S. Kumar. 2011. Antibacterial and antifungal activity of fruiting bodies of Phellinus mushroom extract. Int. J. Biosci., 1(3): 72-77.

Baumert, A., Schumann, B., Pozel, A., Schimidt, J. and D. Strack. 1997. Triterpenoids from Pisolithus tinctorius isolates and ectomycorrhizas. Phytochemistry, 45: 995-1001.

Benedict, R.G. and L. R. Brady. 1972. Antimicrobial activity of mushroom metabolites. J. Pharmacol. Sci., 61: 1820-1822.

Bowers, W. S., Hoch, H. C., Evans, P. H. and M. Katayama. 1986. Thallo phyticallolopathy: Isolation and identification of laetisaric acid. Science., 232: 105-106.

Bowers, W.S., Hoch, H.C., Evans, P.H. and M. Katayama. 1986. Thallophytic allolopathy: Isolation and identification of laetisaric acid. Science., 232: 105-106.

Breene, W. M. 1990. Nutritional and medicine value of speciality macro fungi. J. Food Prot., 53: 883-894.

Bruns, T.D., Bidartondo, M.I. and D.L. Taylor. 2002. Host specificity in ectomycorrhizal communities: What do the exceptions tellus? Integr Comp boil., 42: 352-359.

Fraud, S., Ress, E. L., Mahenthiralingam, E., Russell, A.D and J.Y. Maillard. 2003. Aromatic alcohols and their effect on bacteria, cocci and mycobacteria. J. Chemother., 51: 1435- 1436.

Fujimoto, H., Nakayama, M., Nakayama, Y. and M.Yamazaki. 1994. Chemical \& Pharmaceutical Bulletin., 42: 694.

Gohar, M.Y., El-Naggar, M.A.M., Soliman, K.M. and M.K. Barakat. 2010. Characterization of marine Burkholderia cepacia antibacterial agents. J. Nat. Prod., 3: 86-94. 
Gomez, K.A. and A.A.Gomez. 1984. Statistical procedure for Agricultural Research. John Wiley and Sons, New York, NY, USA.

Hao, J.J., Subbarao, V.K. and M.J. Duniway. 2003. Germination of Sclerotinia minor and $S$. sclerotiorum Sclerotia under various soil moisture and temperature combinations. Phytopathology., 93: 443 - 450 .

Hibbett, D.S. and P.B. Matheny. 2009. The relative ages of ectomycorrhizal mushrooms and their plant hosts estimated using Bayesian relaxed molecular clock analyses. BMC Biol., 7: 1-13.

Holden, M.T.G., Swift, S. and P. Williams. 2000. New signal molecules on the quorum sensing block. Trends Microbiol., 8: 101-103.

Imtiaj, A. and T. S. Lee. 2007. Screening of antibacterial and antifungal activities from Korean wild mushrooms. World J. Agric. sci., 3(3): 316-321.

Kope, H. H and J. A. Fortin. 1990. Antifungal activity in culture filtrates of the ectomycorrhizal fungus Pisolithus tinctorius. Can. J. Bot., 68(6): 1254 1259.

Kope, H. H. and J. A. Fortin. 1989. Inhibition of phytopathogenic fungi in vitro by cell free culture media of ectomycorrhizal fungi. New Phytol., 113: 57-63.

Lazarevic, J., Keca, N. and A. Martinovic . 2012. Mycorrhization of containerized Pinusnigra seedlings with Suillus granulatus under open field conditions. Forest Systems., 21(3): 498-507.

Lincoff, G. H.1984. The Audubon Society Field Guide to North American Mushrooms. New York. 926 p.

Lucie, T.A., Dogo, S. and M.G. Talla. 2013. Chemical characterization and insecticidal activity of ethyl acetate and dichloromethane extracts of Drypetes gossweileri against Sitophilus zeamais, Tribolium castaneum and Rhyzopertha dominica. J. Life Sci., 7(10): 1030-1040.

Marx, D.H. 1973. Mycorrhizae and feeder root diseases. In Ectomycorrhizae: their ecology and physiology. Academic Press, New York. pp. 35: 1-382.

Marx, D.H., Ruehle, J.L. and C.E. Cordell. 1994. Methods for studying nursery and field response of trees to specific ectomycorrhiza. In: Norris, J.R., Read, D.J. and A.K.Varma (eds.),Techniques for the study of Mycorrhizal: Methods in Microbiology. Academic Press, New York. 23: 512p.

Marx, D.H.1970. The influence of ecto tropic mycorrhizal fungi on the resistance to pathogenic infections. Resistance of mycorrhizae to infection by vegetative mycelium of Phytophthora cinnamomi. Phytopathology., 60: 1472-1473.

Mello, A., Ghignone, S., Vizzini, A., Sechi, C., Ruiu, P. and P. Bonfante. 2006. ITS primers for the identification of marketable boletes. J. Biotechnol., 121 (3):318-329.

Mushtaq, A., Rasool, N., Riaz, M., Tareen, R.B., Zubair, M., Rashid, U., Khan, M.A. and Y.H. Taufiq. 2013. Antioxidant, antimicrobial studies and characterisation of essential oil, fixed oil of Clematis graveolens by GC-MS. Oxid. Commun., 36(4): 1067 - 1078.

Oerke, C.E. 2006. Crop losses to pests. J. Agri. Sci., 144: 31-43.

Ross, E.W. and D.H. Marx. 1972. Susceptibility of sand pine to Phytophthora cinnamomi. Phytopathology., 62: 1197-1200.

Salomi, N.J., Nair, S.C. and K.R.Pannikar.1991. Inhibitory effects of Nigella sativa and saffron (Crocus sativus) on chemical carcinogenesis in mice. Nutrition and Cancer., 16: 67-72.

Sangeetha, C., Krishnamoorthy, A.S. and D. Amirtham. 2015. Antifungal bioactive compounds from Chinese caterpillar fungus (Ophiocordyceps sinensis (Berk.) G. H. Sung et al.) against plant pathogens. Madras Agric.J.,102:353-357.

Shrestha, G.V. Shrestha, K. and H. Wallander. 2005. Antagonistic study of ecomycorrhizal fungi isolated from Baluwa forest (central Nepal) against pathogenic fungi and bacteria. Scientific World., 3(3): 49-52.

Smith, S.E. and D. J. Read. 1997. Mycorrhizal symbiosis. 2nd ed. London: Academic Press, London, UK.p 605.

Taylor, A.F.S. and I. Alexander. 2005. The ectomycorrhizal symbiosis: Life in the real world. Mycology., 19: 102-112.

Tsantrizos, Y.S., Kope, H.H., Fortin, A. and K.K.Ogilvie. 1991. Antifungal antibiotics from Pisolithus tinctorius. Phytochemistry., 30: 113-118.

Waser, S.P. 2002. Review of Medicinal Mushrooms Advance: Good News from Old Allies. Herbal Gram. ABC., 56: 28-33.

Zak, B. 1964. Role of mycorrhizae in root disease. Annu. Rev. phytopathol., 2: 377-392.

Zeng, S.R., Mallik, U.A. and E.D. Setlife. 2003. Growth stimulation of ectomycorrhizal fungi by root exudates of Brassicaceae plants: Role of degraded compounds of Indole glucosinolates. J. Chem. Ecol., 29(6): 1337-1355. 